\title{
Kardiologie - jak jsem ji viděl a jaká je
}

\author{
Miloš Štejfa \\ I. interní kardioangiologická klinika, Fakultní nemocnice u sv. Anny a Lékařská fakulta Masarykovy univerzity, Brno, Česká republika
}

Adresa: prof. MUDr. Miloš Štejfa, DrSc., FESC, bývalý přednosta I. interní kardioangiologické kliniky FN u sv. Anny a LF MU, Pekařská 53, 65691 Brno, Česká republika, e-mail: milos.stejfa@seznam.cz

Je pro mne velkou ctí, že jsem byl Českou kardiologickou společností vyzván $\mathrm{k}$ této črtě o kardiologii. Milníky jsou vždy důvodem $\mathrm{k}$ ohlédnutí - $\mathrm{v}$ tomto prrípadě i pro mne obdarovaného stejným výročím.

Česká kardiologická společnost vznikla dne 13. 12.1929 jako třetí na světě, resp. druhá v Evropě. O kardiovaskulární zdraví má v Česku neutuchající zásluhu, zejména díky jejím členům a spolupracovníkům v počátečním období, kdy vedoucí nemocí byly revmatická horečka a porevmatické srdeční vady, i za celou dobu jejího dalšího trvání k dnešním intervenčním metodám. Prof. Zdeněk Fejfar (1916-2003) se spolupracovníky sepsal dějiny společnosti (Česká kardiologie a kardiologové. Praha: Galén, 2001), ke kterým v podstatě není mnoho co dodat, nebot’ kardiologie třetího tisíciletí je teprve v plenkách.

Co asi pro prvního člověka znamenalo, když si uvědomil, že mu buší v hrudi něco, co je spjato nedílně se životem? Nazval to „skokanem“ a nepřekvapí, že přetavené slovo (hrid, krid, a z arménštiny ssird) proniklo do indoevropských jazyků a jeho základ se objevuje ve všech názvech „skokana“ i v evropských řečech ( hrid - Herz, heart, krid cor, cuore, coeur, corazón, a ssird - srdce, serce). Ve starověkých civilizacích bylo srdce, aniž byla známa jeho morfologie a funkce, považováno za sídlo síly, intelektu a lásky (při emoci se vždy rozbuší). Staří Egyptané znali z mumifikací tvar srdce, které znázorňovali jako nádobu na krev, a rozeznali někdy v jeho strukturách tvrdé usazeniny - snad první popis aterosklerózy. Považovali také srdce za sídlo duše, o čemž byly potom vedeny staleté disputace. Křest̉anství dalo symbolu srdce vlastní náplň božské lásky. Symbolika srdce přešla pak do hovorového slovníku, stalo se i symbolem světské lásky, prodejné lásky a součástí lidových rčení. Stylizovaný plochý obraz srdce je také logem většiny kardiologických společností.

Kardiologické objevy na přelomu 19. a 20. století vznikaly většinou v malých univerzitních laboratořích na biologických, patologických a fyziologických ústavech či interních nebo chirurgických klinikách, ale i v soukromí. Uved’me např. Fickův princip (1870), Starlingův zákon (1918), Forsmannovu katetrizaci pravého srdce (1929), objev penicilinu (1929, využit až v padesátých letech), Kleinovo užití srdečního katetru k měření minutového výdeje (1930), srdeční katetrizaci (A. F. Cournand, 1930), měření nitrosrdečních tlaků (J. Lenègre a P. Maurice, 1943).

Brzy byla zjištěna nutnost týmové spolupráce. Vznikaly národní výzkumné kardiologické ústavy, jimž bylo dáno do vínku lepší vybavení a vyšší dotace. Ústav chorob oběhu krevního (ÚCHOK), později Institut klinické a experimentální medicíny (IKEM), byl založen v Praze v roce 1951 jako třetí výzkumný kardiologický ústav na světě, po Instituto Nacional de cardiología v Mexico City v roce 1944 a National Heart, Lung and Blood Institute (NHLBI) v Bethesdě v USA v roce 1948.

$\mathrm{Na}$ interních klinikách či krajských odděleních chabě vybavených se až do konce sedmdesátých let, resp. do začátku osmdesátých let minulého století, provozovala čistě klinická kardiologie. Většina lékařů zaujatých kardiologií musela začít s jednoduchým vybavením, elektrokardiografií anebo zátěžovými testy na „Masterových schůdcích“ a posléze bicykloergometrech. Další možností bylo ověřování účinku léků na malých skupinách probandů, s uspořádáním stanoveným samotným autorem. Následovalo období mechanografické - mechanogramy dlouho sloužily jako referenční metoda - a dále období hemodynamického monitorování, které nyní zůstává vyhrazeno výjimečným př́ípadům. Nové neinvazivní metody, především echokardiografie, pronikaly na kardiologické kliniky a oddělení s obtížemi, jsouce zpočátku obhospodařovány bud' kardiochirurgiemi nebo vznikajícími klinikami zobrazovacích metod. Dlouho nebylo možno prosadit, že kardiovaskulárně nemocní jsou specifickými pacienty, kteří vyžadují často „superakutní echo“, a které je nutno kromě jednorázového vyšetření nebo výkonu dále i sledovat a léčit. Katetrizační sály byly po dlouhou dobu kardiochirurgickou doménou. Pro interní kardiologické kliniky problém vyřešil až příchod intervenční kardiologie. A tak teprve s narůstajícím význa- 
mem ischemické choroby srdeční a srdečního selhání a s rozvojem transplantologie se stav začal napravovat.

Neuvěřitelná exploze kardiologických poznatků vlivem technického rozvoje ve druhé polovině 20 . století vedla k vydělení kardiologie jako specifického oboru.

Až do sedmdesátých let minulého století spočívala léčba ještě na nekontrolovaných zkoumáních $\mathrm{s}$ malým počtem probandů či na retrospektivních studiích určité nemoci („case-control studies“), které přinášely sice určité důležité poznatky, postrádaly však srovnání (protokol vytvářeli výzkumníci sami). K transformaci kardiologie z empirické roviny na úroveň vědeckého poznání došlo vlivem aplikace velkých epidemiologických studií (první byla Framinghamská studie z roku 1948), na kterou od sedmdesátých/osmdesátých let minulého století navázaly velké lékové klinické studie (randomizované, dvojitě slepé). Klinické intervenční studie nových, např. katetrových metod, nebývají tak veliké, jdou ruku v ruce s technologickým pokrokem, a jsou tedy objektivně dokumentované.

Koncem osmdesátých let formulovala na MacMasterově univerzitě v Hamiltonu (Ontario, Kanada) skupina učitelů (D. L. Sackett, R. B. Haynes, W. S. Richardson) metodologii výslovného, vědomého a rozumového využívání zevních vědeckých informací z klinických studií pro diagnostic- ko-léčebné rozhodování. Vznikla tak medicína založená na důkazech (Evidence Based Medicine, EBM). Od té doby se skloňují klinické studie ve všech pádech a jsou podmínkou sestavování doporučení (guidelines, léčebné algoritmy). Diagnostické algoritmy, na nichž správná léčba závisí, jsou však spíše ojedinělé.

Dnes již kardiologie není zvládnutelná jediným mozkem, má řadu rozvětvených podoborů a napojení na další biologické disciplíny. Výzkum potřebuje týmy různých profesí. Svědčí pro to budování univerzitních kampusů s koncentrací lidského i materiálního potenciálu, tj. soustředění mozků i financí. Věda a výzkum vždy kvetly především na univerzitách; důležitým předstupněm by měla být též práce grantových komisí.

Jak se bude kardiologie vyvíjet do budoucna, je velmi těžké odhadnout. Bude přibývat stále dražších vyšetřovacích i intervenčních metod a jejich různých modalit, a bude též přibývat starších pacientů. V oblasti nutné globální reformy zdravotnictví, medicíny a vědy a jejich financování nás čekají prudké peřeje a tichá voda je v nedohlednu.

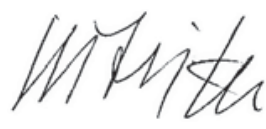

